\title{
Ki-67 Expression in Breast Cancer, Its Correlation with ER, PR and Other Prognostic Factors in Nineveh Province
}

\author{
Hatem Abd-AlMajeed Al-Nuaimi ${ }^{\star}$, Elaf Abdul-Wahhab Hamdi ${ }^{\star *}$, Banan Burhan Mohammed ${ }^{\star \star}$ \\ *Unit of Histopathological Examination, Laboratory of Al-Jumhuri Teaching Hospital, Nineveh - Health Office, \\ Nineveh Province, ${ }^{\star}$ Department of Pathology, College of Medicine, University of Mosul, Nineveh Province, Iraq \\ Correspondence: ela@uomosul.edu.iq
}

(Ann Coll Med Mosul 2020; 42 (1):1-10).

Received: $17^{\text {th }}$ June 2020; Accepted: $19^{\text {th }}$ July 2020.

\begin{abstract}
Objectives: The aggressiveness of malignant tumors of breast can be correlated with the proliferation of neoplastic cells, and this detected by immunohistochemical study of proliferative index (Ki-67). American Society of Clinical Oncology (ASCO) does not recommend the use of Ki-67 routinely to predict the outcome of breast cancers, therefore the aim of current study is to detect the expression of Ki-67 in patients with primary breast cancer in Nineveh Province/North of Iraq and to correlate it with estrogen and progesterone receptors in addition to other prognostic factors.

Methods: In this retrospective-case series study eighty cases of histologically proven primary breast carcinomas were included. The cases were collected from hospitals and private laboratories in Nineveh Province / North of Iraq and studied Immunohistochemicaly for Ki-67, estrogen receptor (ER) and progesterone receptor (PR) were done on tissue sections embedded in paraffin wax. An area with the maximum proliferation was chosen to evaluate $\mathrm{Ki}-67$ and the cases with $\geq 20 \%$ positive nuclei were considered as high Ki-67 expression while those with $<20 \%$ positive nuclei were considered as low Ki-67 expression. The findings of Ki-67 were correlated with the age of the patients, histological type, grade of the tumors and with the estrogen and progesterone receptors.
\end{abstract}

Results: The Ki-67 immunoreactivity was highly expressed in (45\%) of the cases. Estrogen and progesterone receptors observed in (77.5\%) and (67.5\%) of the cases respectively. The Ki-67 was significantly associated with grade of tumor, estrogen receptor and progesterone receptor $(P=0.0057,0.037$ and 0.006 respectively). While the association with patients age and histological types were not statistically significant.

Conclusion: Ki-67 expression shows a significant direct correlation with grade of tumors and a significant inverse correlation has been shown with a well-known predictive factors, (estrogen and progesterone receptors).

Key words: breast cancer, immunohistochemistry, Ki-67, estrogen receptor and progesterone receptor.

$$
\begin{aligned}
& \text { تعبير Ki-67في سرطان الثذي وعلاقتّه مع مستقبلات الاستروجين } \\
& \text { و البروجستيرون و العوامل النذيرية الاخرى في محافظة نينوى مئه مئه }
\end{aligned}
$$

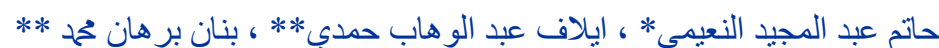

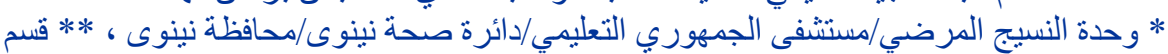

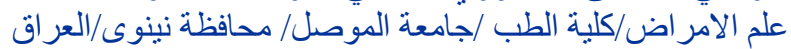

الهيدف : إن عدو انية سرطان الثدي ترتبط بتكاثر الخلايا السرطانية والتي يمكن تحديدها بطريقة كيميائية نسيجية مناعية باستخدام

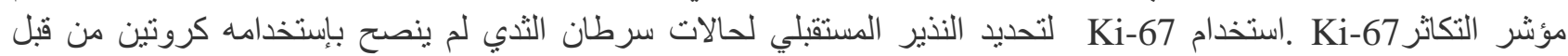

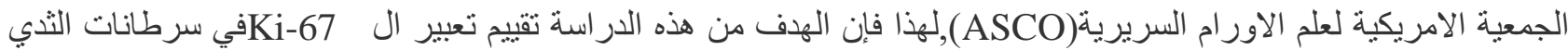

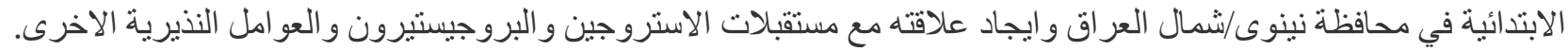

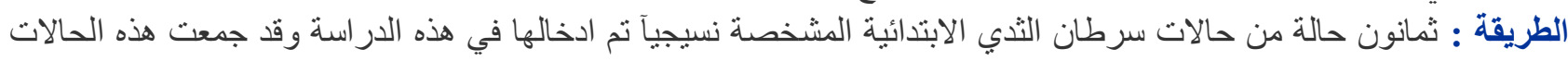
من المستشفيات و العيادات الخاصة في محافظة نينوى/شمال العراق، تم دراسة الآنة Ki-67 ومستقبلات الاستروجين و البروجستيرون 


$$
\begin{aligned}
& \text { بطريقة كيميائية نسيجية مناعية على المقطع النسيجي لكل حالة والمغمورة في شمع البار افين. نتائج تعبير Ki-67 قيمت مع عمر }
\end{aligned}
$$

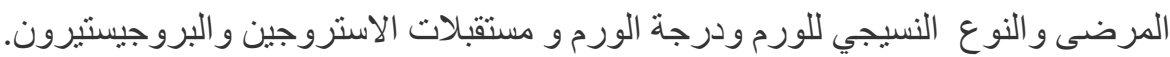

$$
\begin{aligned}
& \text { النتائج : لقد كان منوسط عمر المرضى ك50.4 سنة وسرطان الاقتية غير المحد كان اكثر الانواع النسيجية وشكل } \\
& \text { الحالات وأن 82,6\% من هذه الحالات كانت من الدرجة العالية(درجة I و III). تعبير }
\end{aligned}
$$

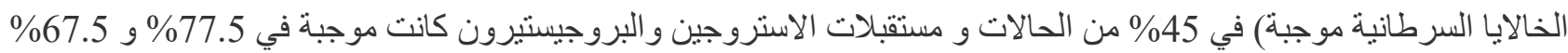

$$
\begin{aligned}
& \text { من الحالات على الترتيب و لقد اظهر Ki-67 علاقة معنوية مع درجة الورم ومستقبلات الاستروجين والبروجستيرون } \\
& \text { الاستخاج }
\end{aligned}
$$

$$
\text { الكلمات المفتاحية : سرطان الثدي, تعبير ال Ki-67, مستقبلات الاستروجين و البروجستيرون. }
$$

\section{INTRODUCTION}

W

orldwide, the most common malignant

tumor in women is the breast cancer (BC)

with an annually new diagnosed cases of more than 1.7 million patients and this number is increasing and may reach up to a 3.2 million per year by $2030 .{ }^{1}$. Since three decades in Iraq, BC is ranking the first among the Iraqi population. ${ }^{2}$, in female BC account up to $29 \%$ of all newly diagnosed cancer and it is responsible for cancer related deaths in $14 \%$ of the cases. ${ }^{3}$. Better outcomes of breast cancer are associated with the expression of ER and PR receptors. ${ }^{4}$, they act as predictors of a good response to hormonal (antiestrogen) therapy. Proliferation rates can give useful information on aggressiveness and prognosis of cancers, also can be used as a guide for treatment regimen in clinical practice. ${ }^{5}$ The Ki67 has emerged as an easy, rapid and economically suitable marker to detect proliferation rate in $\mathrm{BC}^{6}$.

"Ki-67 is a non-histone nuclear cortex protein. ${ }^{7,8}$, involved in the early steps of polymerase 1dependent ribosomal RNA synthesis. It was first identified in a Hodgkin lymphoma in 1983". ${ }^{8}$. "It is expressed in all continuously cycling cells of midG1, S, and G2 phase and in mitosis, but not in the G0 and early $\mathrm{G} 1$ phase"., ${ }^{7,910}$. Ki-67 plays an important role in cell proliferation, but its precise function is still unknown. ${ }^{9}$ So this research is performed on the paraffin embedded blocks of patients with primary breast cancer in Nineveh Province to assess Ki-67 expression, to correlate the Ki-67 findings with patients' age, histological types, grade of tumors, with ER and PR receptors expression, and to detect any significant differences in the current results as compared with that of other studies.

\section{PATIENTS AND METHODS}

This study was reviewed and approved by Medical Research Ethics Committee (MREC), College of Medicine, University of Mosul. In this retrospective-case series study, a formalin-fixed paraffin embedded tissue blocks of an eighty female patients with primary breast cancer were collected from General hospitals and private laboratories in Nineveh province at the north of Iraq during the period from first of October 2017 to first of August 2018. Sections from paraffin embedded tissue which H\&E stained, re-reviewed under light microscope to assess the primary tumor ,the histological types were determined by WHO classification of breast tumors and graded by Modified Bloom-Richardson grading system. The age of the patients was retrieved from the medical reports. One section from each case was selected for immune-histochemical study.

\section{Immunohistochemistry}

Each case was studied for ER, PR and Ki-67. The antibodies, buffers, glass slides and linking systems were purchased from DAKO ${ }^{\text {TM }}$ (Dako/Denmark). Sections of 4 millimeter thickness were deparaffinized in xylene and dehydrated, the immunohistochemical study was performed according to manufacturer instructions. Primary 
antibodies used for ER was (1D5 Dako Cytomation, dilution 1:100), for PR was (PgR636 Dako Cytomation, dilution 1:100) and for Ki-67 was (MIB-1 (M7240; Dako Cytomationdilution, dilution $1: 100)$ ). With each run a positive and negative controls were included. Negative controls were prepared by replacing the primary antibody with Tris-buffered saline, positive control slides for ER and PR were obtained from breast carcinoma known to be positive for the hormone receptors while for Ki-67 a sections from tonsils were used as positive controls.

\section{Immunohistochemical Evaluation}

The immunostaining of ER, PR and Ki-67 appear as brown nuclear stain. All slides were evaluated for this immune-staining by light microscopy using a Leitz dialux microscope. Regarding the ER and PR expression the cases were considered positive if $\geq 10 \%$ of the neoplastic cells showed positive nuclear staining. ${ }^{10}$. Ki-67 was expressed as a percentage of positively stained cells per 100 epithelial cells after counting at least 1000 cells using high power (400X). An area with the maximum proliferation was chosen to evaluate $\mathrm{Ki}$ 67 and the cases with $\geq 20 \%$ positive nuclei were considered as high $\mathrm{Ki}-67$ expression while those with $<20 \%$ positive nuclei were considered as low Ki-67 expression. ${ }^{10-14}$.

\section{Statistical Analysis}

The association between Ki-67 and variable categories was assessed using Chi-square test and Fisher Exact test when indicated. Regarding statistical analyses, the $P$ value considered statistically significant if its $<0.05$.

\section{RESULTS}

The patients' age ranged from $24-74$ years (mean $=50.4$ ) with 43 cases $(53.75 \%$ ) were younger than 50 years. Regarding the histological types of the cases were included in the study; the majority of cases (69 out of 80 ) were of IDC-NOS, which form $86.25 \%$ of all the cases, the remaining cases were: 8 cases invasive lobular carcinoma (ILC) which form $10 \%$ and 3 cases were ductal carcinoma in situ (DCIS) which form $3.75 \%$ of all cases. Concerning the grading of IDC-NOS that were included in this study; 12 cases (17.4\%) were of grade I, grade II were 25 cases (36.2\%) and 32 cases $(46.4 \%)$ were of grade III. The ER was found to be positive in 62 cases (77.5\%) while PR was positive in 54 cases (67.5\%), [Figure 1]. Immunohistochemical study of Ki-67 showed highly expression $(\geq 20 \%$ of nuclei were positive) in 36 $(45 \%)$ of patients and low expression was observed in 44 cases (55\%), [Figure 2]. The patients' characteristics are summarized in table(1).

The correlation of Ki-67 expression with the age of the patients and the histological types were not significant statistically $(P$ value 0.333 and 0.682 respectively). A significant direct association of $\mathrm{Ki}$ 67 expression with the grade was observed $(P=0.0057)$ while inverse relation was found between Ki-67 expression and ER positivity that is a high Ki-67 expression was associated with decreased ER positivity, this association was statistically significant $(P=0.037)$. The same trend was found with PR positivity and also the relation was statistically significant $(P=0.006)$.

Regarding the hormonal status, more than half of the patients (53 cases which form 66.25\%) were positive for both ER and PR (ER+PR+), 36 cases $(45 \%)$ of them showed low Ki-67 expression, 9 cases $(11.25 \%)$ were ER+PR-, 7 cases of them had a high Ki-67 expression, only one case $(1.25 \%)$ was ER-PR+ and it showed a high Ki-67 expression, while 17 cases (21.25\%) were ER-PRand 11 cases of them showed a high Ki-67. This inverse relation of Ki-67 with hormonal status was statistically significant $(P=0.0054)$. Tables ( 2 and 3 ) summarized the relation of $\mathrm{Ki}-67$ with various parameters and with histological types respectively.

\section{DISCUSSION}

The age of patients included in this study were ranged from 24 to 74 years (mean $=50.4$ ), this result is very near to that of another Iraqi study done in 2016 in Baghdad by Al-Rawaq ${ }^{15}$, in which the mean of age was 51 with the range of 27-73, also it somewhat nears to another study done in Nineveh Province by Al -Nuaimy ${ }^{16}$, in 2015. However the result is more or less within those of others. $4,6,9,11,12,17,18,19$, this may be due to genetic difference, hereditary factors, socio-demographic factors, the age of menarche, parity and time of first delivery in addition to the close relative 
marriages which are common in Iraq. Obesity and Lack of exercise which have been newly prevalent in Iraq can be added.

Forty three $(53.75 \%)$ of the cases included in this study were less than 50 years old while $46.25 \%$ were 50 years or older, this result is opposite to what is known about the increasing incidence of $\mathrm{BC}$ with age, however this result is similar to that recorded by other Iraqi studies, that $54.7 \%$ and $58 \%$ of the cases included in a studies done by $\mathrm{Al}$ Nuaimy ${ }^{16}$, and Mahmoud ${ }^{20}$ respectively, were younger than 50 years. This also may be due to socio-demographic factors, genetic difference, age of menarche, time of first delivery, parity, traditional marriages among first-degree relatives ${ }^{16}$. In addition may be attributed to effect of the wars that Iraq was exposed, that make Iraqi people exposed to a lot of chemical carcinogenic material and radiation. More researches are needed in this locality to determine the predisposing factors for this result.

In this study, the IDC-NOS was the most common histological type which form $86.25 \%$ of the cases, and this result is near to that found by Neelakanth ${ }^{21}$, where $90.7 \%$ of the cases were IDC-NOS, the result also somewhat near to that of Mahmoud ${ }^{(20)}$,who observed that $93.5 \%$ of the cases included his study were of IDC-NOS and also it was the most common in other studies $4,9,10,13,16$

Regarding the histological grade of tumor, the maximum number of IDC-NOS cases (82.6\%) that included in this study were presented with high grade (grade II and III), with $46.4 \%$ of them were of grade III, this result is similar to that of a study done in Kirkuk/Iraq in 2014 by Mahmoud ${ }^{20}$ in which grade III was formed $46.4 \%$ of his cases. Also Grade III was common (53\% of the cases) in a study done by Soliman ${ }^{9}$ in Egypt. However this result is differ from that observed by others. ${ }^{4,12,16}$ where grade II was the most common, this may be attributed to difference in demographic characteristics, racial backgrounds or probably reflecting tumor cell heterogeneity.

In the current study, a positive immunohistochemical ER and PR were observed in $77.5 \%$ and $67.5 \%$ respectively, these results were near to that study done in Morroco in 2016 by Mahir W et al. ${ }^{19}$ which showed that ER and PR were positive in $73.1 \%$ and $69.1 \%$ respectively, Furthermore, the result of this study also relatively near to that of a study done in Baghdad in 2015 by Al-Sarraf ${ }^{4}$ in which $75 \%$ and $72.5 \%$ of the cases showed a positivity for ER and PR respectively and consistent with other study done also in Baghdad in 2012 by Elyass ${ }^{22}$, where ER and PR were positive in $72 \%$ and $68 \%$ of the cases respectively, However different results were seen by others.

Table (4). The variation in the findings of these studies may be due to variation in the IHC staining technical operation with different manufacturers, variation of kits and types of antibodies which were used in these studies in addition to the variation of patients' age group.

\section{The Expression of Ki-67 in This Study and Its Relation with Various Parameters}

"Ki-67 antigen was detected in the early steps of polymerase I-dependent ribosomal RNA synthesis". ${ }^{14}$. Despite Ki-67 protein has a significant role in cell proliferation, but its precise function is still unknown and there is few published researches on its role. ${ }^{14}$. A number of researches have studied the prognostic significance of Ki-67 in breast cancer. But no similar study was done in Nineveh province. So the current study was also done to evaluate the prognostic significance of $\mathrm{Ki}$ 67 in primary breast cancer by correlating it with traditional well known clinicopathological prognostic parameters like age of the patients, histological types, grade of tumor, and its correlation with the ER and PR which are most useful markers in predicting response to hormonal therapy.

Despite the presence of a large number of published researches reporting a significant results regarding the Ki-67, but still the cut-point for differentiate a BC patients with low Ki-67 expression from a high expression is currently debatable ${ }^{23,24}$, which was varied from 1 to $29 \%$ and this may be the cause for limiting its clinical utility. ${ }^{24}$. The St. Gallen Consensus in 2009, classify Ki-67 expression into: low $<15 \%$, intermediate $16-30 \%$ and high $>30 .{ }^{24,25}$. Then St. Gallen in 2011 proposed Ki-67 cut-point at 14\% and use it to separate ER + tumors into luminal $A$ 
(Ki-67<14\%) and luminal B (Ki-67>14\%). ${ }^{13,24}$, but 2 years later, it was upgraded "to $20 \%$ with the option to also use locally specified cut-points". ${ }^{13,26}$, then St. Gallen Breast Cancer Conference in 2015 has been recommended a median cut-off value of $\mathrm{Ki}-67$ within the range of $20-29 \%$ in order to define 'luminal B-like'. ${ }^{10}$. In 2016 a study was done by Bustreo et al. ${ }^{13}$ on 1.577 HER2-/ER+ breast cancer patients having full clinical, histolopathological, and follow-up data, and they use two Ki-67 cut-offs (14 and $20 \%$ ) and correlated them with disease-free interval (DFI) and disease-specific survival (DSS). They found that patients having tumors with Ki-67<14\% did not differ from those with Ki-67 values between 14 and $20 \%$ regarding DFI and DSS, while the poorest prognosis was observed in those patients having tumor with $\mathrm{Ki}-67>20 \%$. In the current study, the $20 \%$ as a cutoff value for Ki-67 was used, also this cut-point was used by other studies. ${ }^{10-14}$.

In this study, the high Ki-67 expression was observed in 36 cases (45\%). This is consistent with that study done by Madani ${ }^{18}$ in Iran in 2016 in which a high expression of Ki67 were observed in $44.6 \%$ of the cases and also the result near to that found by Joensuu K. ${ }^{7}$ in Finland were $43 \%$ of the cases showed a high Ki-67 expression, however the result of this study is differ from that of others, see table (4).

The commonest way to study $\mathrm{Ki}-67$ expression is immunohistochemical (IHC) staining by MIB-1 antibody. Different antibodies such as Ki-S5, MIB$1, \mathrm{MM}-1$, and SP-6 were used in different studies. ${ }^{8,14,25}$, this might be a reason for this considerable variation. Also these variations may be attributed to different groups of population, different methods for detecting $\mathrm{Ki}-67$ and different cutoffs to differentiate a high $\mathrm{Ki}-67$ expression from a low. ${ }^{27}$. In addition to that there is variation in Ki-67 scoring that, some of the pathologists use the percentage of nuclei staining; while others enumerate several hundred nuclei in different areas of tumors to get an overall average index. ${ }^{25}$.

The relation of Ki-67 expression with the age of the patients was not statistically significant $(P=0.333)$, this result is similar to that of others. ${ }^{9,23}$ , however the Liu et al. $^{12}$ found a significant relation of Ki-67 with the age, that patients with higher Ki-67 expression were younger than those with lower Ki-67 expression. No significant relation was found between Ki-67 and histological types, while Neelakanth ${ }^{21}$ found a significant relation with histological type, relatively small numbers of nonductal types included in this study may be the cause of this result, however Soleman ${ }^{9}$ and Ermiah et al. $^{23}$ also found no significant relation between Ki-67 and the tumor histological type.

A definite significant correlation between the $\mathrm{Ki}$ 67 expression and tumor grade has been documented in several studies. $5,6,9,12,21,23,26,27$, a similar result was observed in the current study, this is due to that mitotic index is one of the three components of the Modified Bloom-Richardson grading system of $\mathrm{BC}{ }^{21}$. It is well known that histologic grade has been associated with poor prognosis. ${ }^{21}$ In current study Ki-67 expression was found increase with increasing the grade of tumor. This goes with the well-established view, that proliferating cells usually do not differentiate while cells when differentiating, usually stop dividing. ${ }^{21}$.

Regarding the hormonal status, most of the breast cancer patients $(66.25 \%$ of the cases) in the current study were hormonal receptors positive (ER+PR+), this result is similar to that of Al Sarraf ${ }^{4}$ and Al-Rawaq ${ }^{15}$. Hormonal receptors, which are well known predictive and prognostic biomarkers, were used to determine benefit from endocrine therapies in BC. A significant inverse relation was observed between $\mathrm{Ki}-67$ and $\mathrm{ER}$ and between $\mathrm{Ki}-$ 67 and PR that is patients with ER- and / or PRare more possibility to have a higher $\mathrm{Ki}-67$ expression, this result was also observed by others. ${ }^{5,9,12,23,26,28}$ Liu et al. ${ }^{12}$ in their study were concluded that the $\mathrm{BC}$ with high $\mathrm{Ki}-67$ expression has a poor prognosis but responds better to neoadjuvant chemotherapy, this may be due to the fact that dividing cells have increased sensitivity to cytotoxic drugs ${ }^{29}$. Faneyte et al. ${ }^{30}$ observed that Ki-67 was significantly declined after chemotherapy, also they observed that a patients with $\mathrm{BC}$ that have a negative ER and a high Ki-67 expression are associated with better response. ${ }^{30}$.

So in the BC, Ki-67 expression may be considered as a predictive marker that can be added to ER and PR to predict the prognosis. A large prospective study of DFS and OS among BC 
patients with various $\mathrm{Ki}-67$ expression and various ER/PR cancer phenotypes is needed to determine the prognostic and predictive effect of Ki- 67 .

\section{CONCLUSION}

the current study a high Ki-67 expression was found in $45 \%$ of a female with BC in Nineveh Province /north of Iraq. No significant relation was found among Ki-67 with the age of patients and histological types of $\mathrm{BC}, \mathrm{A}$ direct significant relation was observed between the Ki-67 expression and grade of tumor while Ki-67 was inversely associated with a well-known predictive factors (ER and PR). Further study with follow-up of the $\mathrm{BC}$ patients with various Ki-67 expression and various $E R / P R$ cancer phenotypes is required to improve the prognostic and predictive role of $\mathrm{Ki}-67$ in $\mathrm{BC}$.

\section{RECOMMENDATION}

Table (1): The data of the patients included in this study
- More studies are advised in our locality to detect the predisposing factors for occurrence of $\mathrm{BC}$ in younger age groups among Iraqi population.

- The Ki-67 is an immunohistochemical marker which determines the proliferative activity of tumor, so can give an idea about the aggressiveness of tumor and the patients prognosis.

-The Ki-67 can be used to make a subclassification of the patients, and can be used with other immunohistochemical markers (ER and PR) for better classification of patients, to include them under appropriate treatment regimens and to avoid them the ineffective therapy.

-Further study with follow-up of the patients with breast cancer with various Ki-67 expression and various ER/PR cancer phenotypes is required to prove the predictive and prognostic effect of this marker.

\begin{tabular}{|c|c|c|c|}
\hline & & No. & $\%$ \\
\hline \multirow[t]{2}{*}{ Age } & $<50$ & 43 & $53.75 \%$ \\
\hline & $\geq 50$ & 37 & $46.25 \%$ \\
\hline \multirow{3}{*}{ Histological type } & IDC-NOS & 69 & $86.25 \%$ \\
\hline & ILC & 8 & $10 \%$ \\
\hline & DCIS & 3 & $3.75 \%$ \\
\hline \multirow{3}{*}{ Grade of IDC-NOS } & 1 & 12 & $17.4 \%$ \\
\hline & $\pi$ & 25 & $36.2 \%$ \\
\hline & III & 32 & $46.4 \%$ \\
\hline \multirow[b]{2}{*}{ Estrogen receptor } & Positive & 62 & $77.5 \%$ \\
\hline & Negative & 18 & $22.5 \%$ \\
\hline \multirow{2}{*}{ Progesterone receptor } & Positive & 54 & $67.5 \%$ \\
\hline & Negative & 26 & $32.5 \%$ \\
\hline \multirow{4}{*}{ Hormonal receptors status } & ER+PR+ & 53 & $66.25 \%$ \\
\hline & ER+PR- & 9 & $11.25 \%$ \\
\hline & ER-PR+ & 1 & $1.25 \%$ \\
\hline & ER-PR- & 17 & $21.25 \%$ \\
\hline \multirow[b]{2}{*}{$\mathrm{Ki}-67$ expression } & High & 36 & $45 \%$ \\
\hline & Low & 44 & $55 \%$ \\
\hline \multicolumn{2}{|c|}{ Total no. of the cases } & 80 & $100 \%$ \\
\hline
\end{tabular}


Table (2): Relation of Ki-67 expression with the different parameters

\begin{tabular}{|c|c|c|c|c|c|}
\hline \multicolumn{2}{|c|}{ Parameters } & \multicolumn{2}{|c|}{$\overline{\mathrm{Ki}-67}$} & \multirow[t]{2}{*}{ Total } & \multirow[t]{2}{*}{ P-value } \\
\hline & & High expression & $\begin{array}{c}\text { Low } \\
\text { expression }\end{array}$ & & \\
\hline \multirow[b]{2}{*}{ Age of patients } & $<50$ year & $22(27.5 \%)$ & $21(26.25 \%)$ & $43(53.75 \%)$ & \multirow[b]{2}{*}{0.333} \\
\hline & $\geq 50$ year & $14(17.5 \%)$ & $23(28.75 \%)$ & $37(46.25 \%)$ & \\
\hline \multirow{3}{*}{ Grade of tumor } & Grade I & $2(2.9 \%)$ & $10(14.5 \%)$ & $12(17.4 \%)$ & \multirow{3}{*}{0.0057} \\
\hline & Grade II & $18(26.1 \%)$ & $7(10.1 \%)$ & $25(36.2 \%)$ & \\
\hline & Grade III & $16(23.2 \%)$ & $16(23.2 \%)$ & $32(46.4 \%)$ & \\
\hline \multirow[b]{2}{*}{ ER } & Positive & $23(28.75 \%)$ & $38(47.5 \%)$ & $61(76.25 \%)$ & \multirow{2}{*}{0.037} \\
\hline & Negative & $13(16.25 \%)$ & $6(7.5 \%)$ & $19(23.75 \%)$ & \\
\hline \multirow[b]{2}{*}{ PR } & Positive & $18(22.5 \%)$ & $36(45 \%)$ & $54(67.5 \%)$ & \multirow{2}{*}{0.006} \\
\hline & Negative & $18(22.5 \%)$ & $8(10 \%)$ & $26(32.5 \%)$ & \\
\hline \multirow{4}{*}{$\begin{array}{l}\text { Hormonal receptors } \\
\text { (ER and PR) status }\end{array}$} & $\mathrm{ER}+\mathrm{PR}+$ & $17(21.25 \%)$ & $36(45 \%)$ & $53(66.25 \%)$ & \multirow{4}{*}{0.0054} \\
\hline & ER+PR- & $7(8.75 \%)$ & $2(2.5 \%)$ & $9(11.25 \%)$ & \\
\hline & ER-PR+ & $1(1.25 \%)$ & $0(0 \%)$ & $1(1.25 \%)$ & \\
\hline & ER-PR- & $11(13.75 \%)$ & $6(7.5 \%)$ & $17(21.25 \%)$ & \\
\hline
\end{tabular}

Table(3):Relation of Ki-67 with histological type of tumors.

\begin{tabular}{|c|c|c|c|c|}
\hline Histological types & \multicolumn{2}{|c|}{ Ki-67 expression } & Total & P value \\
\hline & high & low & & \\
\hline IDC-NOS & $30(37.5 \%)$ & $39(48.75 \%)$ & $69(86.25 \%)$ & \\
\cline { 1 - 4 } ILC & $4(5 \%)$ & $4(5 \%)$ & $8(10 \%)$ & \multirow{2}{*}{0.682} \\
\hline DCIS & $2(2.5 \%)$ & $1(1.25 \%)$ & $3(3.75 \%)$ & \\
\hline Total & $36(45 \%)$ & $44(55 \%)$ & $80(100 \%)$ & \\
\hline
\end{tabular}

Table(4): The number and percentage of high Ki-67 expression and the percentage of positive ER and PR in the breast cancer cases included in the current study and other studies.

\begin{tabular}{|c|c|c|c|c|c|c|}
\hline Studies & Year & Region & $\begin{array}{c}\text { High Ki-67 } \\
\text { No. (\%) }\end{array}$ & ER\% & PR\% & $\begin{array}{c}\text { Total } \\
\text { No. of } \\
\text { cases }\end{array}$ \\
\hline Current study & 2018 & Nineveh/Iraq & $36(45 \%)$ & $77.5 \%$ & $67.5 \%$ & 80 \\
\hline Liu Z et al. $^{12}$ & 2017 & China & $249(62.6 \%)$ & $56.5 \%$ & $18.1 \%$ & 398 \\
\hline Kombak FE et al. $^{17}$ & 2017 & Turkey & $154(65.2 \%)$ & $82.7 \%$ & $75.7 \%$ & 236 \\
\hline Elkablawy MA. $^{6}$ & 2016 & Kingdom of Saudi Arabia & $85(73.9 \%)$ & $61.8 \%$ & $62.7 \%$ & 115 \\
\hline Soliman NA. $^{9}$ & 2016 & Egypt & $36(33.8 \%)$ & $53.3 \%$ & $55.1 \%$ & 107 \\
\hline Al-Rawaq KJ. $^{15}$ & 2016 & Baghdad//raq & $69(69 \%)$ & $74 \%$ & $75 \%$ & 100 \\
\hline Madani SH. $^{18}$ & 2016 & Iran & $116(44.6 \%)$ & $60 \%$ & $57.3 \%$ & 260 \\
\hline Al-Sarraf FS. $^{4}$ & 2015 & Baghdad//raq & $23(57.5 \%)$ & $75 \%$ & $72.5 \%$ & 40 \\
\hline Joensuu K. & 2013 & Finland & $31(43 \%)$ & $68 \%$ & $53 \%$ & 72 \\
\hline Ermiah E et al. $^{23}$ & 2012 & Libya & $76(76 \%)$ & $67 \%$ & $55 \%$ & 100 \\
\hline
\end{tabular}




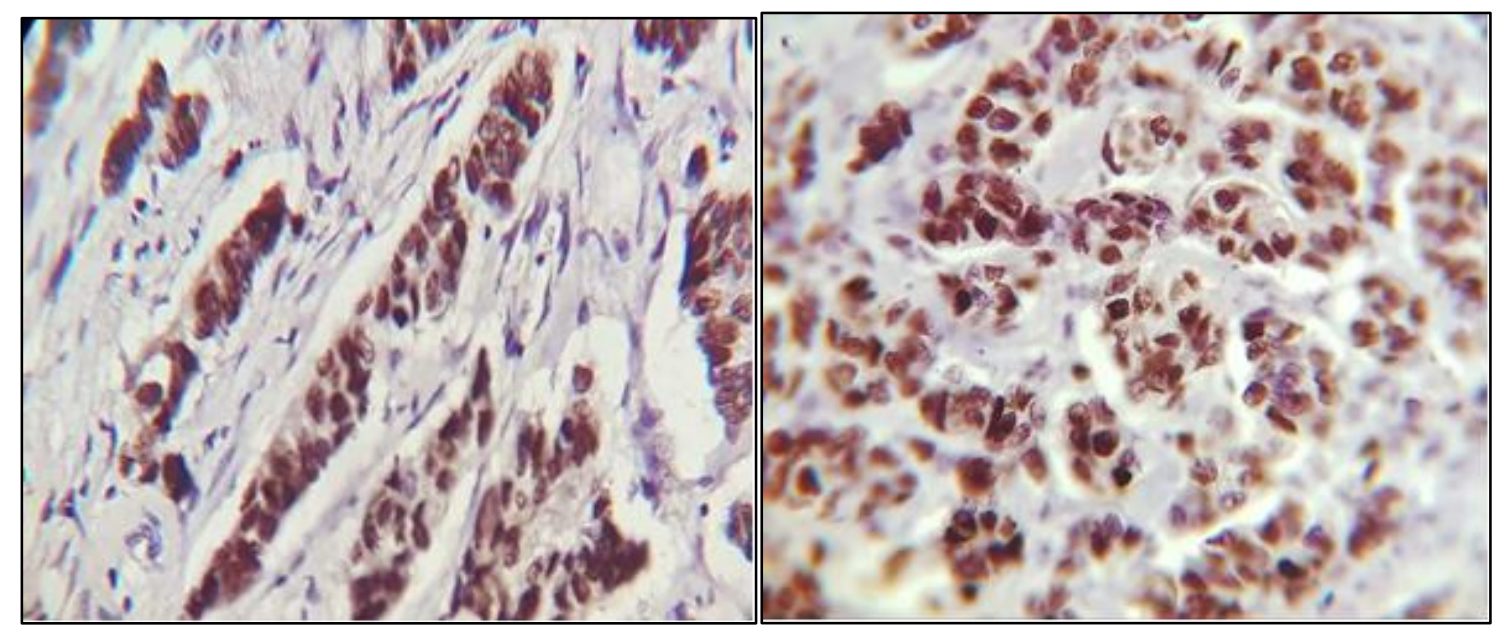

Figure (1): Breast cancer positive for hormone receptors. Left, positive for ER and right, positive for PR (X400).

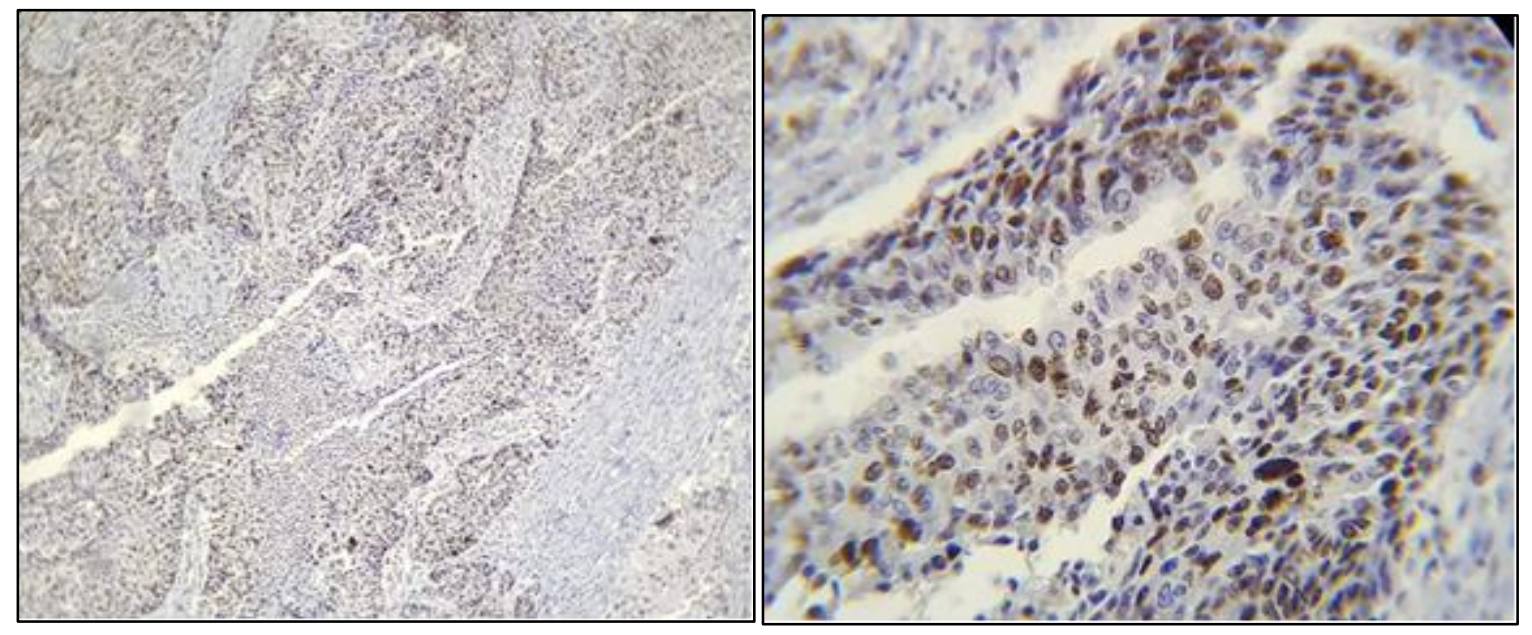

Figure (2): High Ki-67 expression in breast cancer (left X40 and right X400)

\section{REFERENCES}

1-Ramkumar C, Prakash Ch, Madhav L, Kumar A, Basavaraj C, Prathima R, et al. Assessment of Ki67 as prognostic marker in hormone receptor positive breast cancer: Aretrospective study on An India Cohort. J Mol. Biomark Diagn 2017;8(3):1-7.

2-Alwan NAS, Tawfeeq FN, Muallah FH. Breast Cancer Subtypes among Iraqi Patients: Identified By Their ER, PR and HER2 Status. J Fac Med Baghdad 2017;59(4):303-7.

3-Al-Aubaidi TI, Ahmed M. Correlation between the histopathological grade and size of breast cancer with axillary lymph node involvement. JFac Med Baghdad 2017; 59(4):294-8.

4-Al-Sarraf FS, Hussien IA. Evaluation of the proliferation marker Ki-67 as a prognostic factor in patients with breast carcinoma. Fac Med Baghdad 2015; 57(2):151-5.

5-Khanna M, Sharma M, Manjari M, Kaur K, Garg S, Goyal S. Correlation of Ki-67 with ER, PR, Her2neu and other Prognostic Factors In Breast Carcinoma. Annals of Pathology and Laboratory Medicine 2016; 3(6):540-4. 
6-Elkablawy MA, Albasri AM, Mohammed RA, Hussainy AS, Nouh MM, Alhujaily S. Ki-67 expression in breast cancer. Correlation with prognostic markers and clinicopathological parameters in Saudi patients. Saudi Med J. 2016; 37(2): 137-41.

7-Joensuu K, Leidenius M, Kero M, Andersson LC, horwitz KB, Heikkilä P. ER, PR, HER2, Ki-67 and CK5 in early and Late Relapsing Breast cancer-Reduced cK5 expression in Metastases. Breast Cancer: Basic and Clinical Research 2013;7:23-34. doi: 10.4137/BCBCR.S10701.

8- Penault - Llorca F, Radosevic-Robin N. Ki67 assessment in breast cancer: an update. Pathology 2016; 11: 1-6.

9-Soliman N, Yussif Sh M. Ki-67 as a prognostic marker according to breast cancer molecular subtype. Cancer Biol Med 2016; 13(4):496-504. doi: 10.20892/j.issn.2095-3941.2016.0066

10-Rossi L, Lass E, Mallon P, Vincent-Salomon A, Guinebretiere J-M, F Lerebours F. et al. Prognostic impact of discrepant Ki67 and mitotic index on hormone receptor-positive, HER2negative breast carcinoma. British journal of cancer 2015;113:996-1002. doi: 10.1038/bjc.2015.239.

11- Nishimiya H, Kosaka Y, Yamashita K, Minatani $\mathrm{N}$, Kikuchi M, Ema A, et al. Prognostic Significance of Ki-67 in Chemotherapy-naïve Breast Cancer Patients with 10-year Follow-up. Anticancer Research 2014; 34 (1):259-68.

12-Liu Z, Zhang C, Zhuo P, He K, Wang X, Yu Q, et al. Characteristic of ER+/PR- and Ki-67 value with breast cancer. Int $J$ Clin Exp Med 2017;10(2):3533-9. www.ijcem.com /ISSN:19405901/IJCEM0041032

13-Bustreo $S$, Osella-Abate $S$, Cassoni $P$, Donadio M, Airoldi M, Pedani F. et al. Optimal Ki-67 cut-off for luminal breast cancer prognostic evaluation: a large case series study with a longterm follow-up. Breast Cancer Res Treat 2016;157(2):363-71.DOI 10.1007/s10549-0163817-9.

14-Stathopoulosa G.P, Malamosb NA, Markopoulosc C, Polychronisa A, Armakolasa A, Rigatos $\mathrm{S}$, et al. The role of $\mathrm{Ki}-67$ in the proliferation and prognosis of breast cancer molecular classification subtypes. Anti-Cancer Drugs 2014; 25:950-7. DOI: 10.1097/CAD.0000000000000123.

15-Al-Rawaq KJ, Al-Naqqash MA, Jassim MK. Molecular Classification of Iraqi Breast Cancer Patients and Its Correlation with Patients' Profile. Fac Med Baghdad 2016; 58(3): 197-201.

16-Al-Nuaimy WMT, Ahmed AH and Al-Nuaimy HA. Immunohistochemical Evaluation of Triple Markers (ER, PR and HER-2/neu) in Carcinoma of the Breast in the North of Iraq. Donn. J. Med. Lab. Diagn 2015; 1(1):1- 9.

17-Kombak FE, Sahin H, Mollamemisoglu H, Önem I, Kaya $\mathrm{H}$, Bugdayci $\mathrm{O}$ et al. Concordance of immune-histochemistry between core needle biopsy and surgical resection of breast cancer. Turk J Med Sci 2017;47:1791-6.

18- Madani SH, Payandeh M, Sadeghi E. The correlation between ki-67 with other prognostic factors in breast cancer: A study in Iranian patients. Indian J Paediatr Oncol. 2016;37(2):959.

19- Mahir W, Rouas L, Ouzir M, Ferhati D, Rhrab B, Alhamany Z, et al. Correlation of ER, PR and HER2 with Clinic-pathological Parameters in infiltrating ductal Carcinoma of Breast in Morocco. International Journal of Innovation and Applied Studies 2016; 14(2):498-506.

20-Mahmoud MM. Breast Cancer in Kirkuk City, Hormone Receptors Status (Estrogen and Progesterone) and Her-2/Neu and Their Correlation with Other Pathologic Prognostic Variables. Diyala Journal of Medicine 2014; 6(1):1-14.

21-Neelakanth SS, Suchitha S, Manjunath VG. A study of $\mathrm{Ki} 67$ immuno-staining in breast carcinomas: Correlation with histopathological prognostic factors. Indian Journal of Pathology and Oncology 2017; 4(1):98-102. DOI: 10.18231/2394-6792.2017.0019.

22-Elyass TYM. Molecular Study of Human Mammary Tumor Virus and Immunohistochemistry of Hormonal Receptors in women with Breast Carcinomas. MSc Med. Microbiol. Thesis. Baghdad College of Medicine, 2012.

23-Ermiah E, Buhmeida A, Abdalla F, Khaled BR, Salem N, Pyrhönen1 S, et al. Prognostic Value of Proliferation Markers: Immunohistochemical Ki-67 Expression and Cytometric S-Phase action 
of Women with Breast Cancer in Libya. Journal of Cancer 2012; 3: 421-31.

24-Juhasz-Böss I, Mavrova R, Simona M, Radosa JC, Gilda S, Bohle RM, et al. Can Ki-67 Play a Role in Prediction of Breast Cancer Patients' Response to Neoadjuvant Chemotherapy? BioMed Research International 2014; 2014: 1-7.

25- Muftah AA, Aleskandarany MA, Al-kaabi MM, Sonbul SN, Diez-Rodriguez M, Nolan CC, et al. Ki67 expression in invasive breast cancer: the use of tissue microarrays compared with whole tissue sections. Breast Cancer Res Treat 2017; 164: 341-8. DOI 10.1007/s10549-017-4270-0.

26- Ragab HM, Samy N, Afify M, Abd El Maksoud $\mathrm{N}$, Shaaban HM. Assessment of $\mathrm{Ki}-67$ as Apotential Biomarker in Patients with Breast Cancer . Journal of Genetic Engineering and Biotechnology 2018;16:479-84.

27-Haroon S, Hashmi AA, Khurshid A, Kanpurwala MA, Mujtuba S, Malik B, et al. Ki67 Index in Breast Cancer: Correlation with Other Prognostic Markers and Potential in Pakistani Patients. Asian Pac J Cancer Prev, 2013;14 (7): 4353-8.

28-Mandó $P$, Rizzo $M$, Puente $C P$, Maino $M$, Ponce C, Pombo MT, et al. High Histologic Grade and High Ki-67 Expression Predict Phenotypic Alterations in Node Metastasis in Primary Breast Cancers. J Breast Cancer 2017; 20(2): 170-5.

29- Mannell A. The role of Ki-67 in breast cancer.

S Afr Surg 2016;54(2):10-3.

30-Faneyte IF, Schrama JG, Peterse JL, Remijnse $\mathrm{PL}$, Rodenhuis S, Vijver MJ. Breast cancer response to neoadjuvant chemotherapy: predictive markers and relation with outcome. British Journal of Cancer 2003; 88: $406-12$. doi:10.1038/sj.bjc.6600749 www.bjcancer.com 